\title{
Chinese and white Canadian satisfaction and compliance with physicians Richard Liu ${ }^{1}$, Lawrence So ${ }^{2,3}$ and Hude Quan*2,3
} Address: ${ }^{1}$ Faculty of Medicine and Dentistry, University of Alberta, Canada, ${ }^{2}$ Department of Community Health Sciences, University of Calgary,
Canada and ${ }^{3}$ The Center for Health and Policy Studies, University of Calgary, Calgary, Alberta, Canada

Email: Richard Liu - ryliu@ualberta.ca; Lawrence So - lso@ucalgary.ca; Hude Quan* - hquan@ucalgary.ca

* Corresponding author

Published: 21 March 2007

BMC Family Practice 2007, 8: I I doi: | 0.1 | 86//47|-2296-8-I I
Received: 12 September 2006

Accepted: 2I March 2007

This article is available from: http://www.biomedcentral.com/I47/-2296/8/II

(C) 2007 Liu et al; licensee BioMed Central Ltd.

This is an Open Access article distributed under the terms of the Creative Commons Attribution License (http://creativecommons.org/licenses/by/2.0), which permits unrestricted use, distribution, and reproduction in any medium, provided the original work is properly cited.

\begin{abstract}
Background: Patient satisfaction has become an important indicator of primary care and healthcare system performance. Ethnic disparities in patient satisfaction and compliance with physician care have been studied in several countries. However, this issue has not received significant attention in Canada. The unique characteristics of the Canadian healthcare system and ethnic population make it worthwhile to examine this issue in this population. Therefore, we conducted a survey among Chinese and Whites in a Canadian city to determine their reported satisfaction, and perceptions of physicians.
\end{abstract}

Methods: The survey was conducted in English, Mandarin and Cantonese in 2005 among Chinese and White Canadians, 18 years of age or older, who had visited at least one physician in Canada.

Results: We analyzed 746 Chinese and 7II Whites in the general practitioner (GP) visit group and 485 Chinese and 637 Whites in the specialist visit group. A lower proportion of Chinese compared to Whites reported that they were very satisfied or satisfied with GP $(73.7 \%$ vs. $92.8 \%)$ and specialist care $(75.5 \%$ vs. $85.6 \%)$ and the differences between the two groups remained after adjustment for demographic variables and chronic conditions (risk adjusted OR: $0.70,95 \% \mathrm{Cl}: 0.42$ I. 18 for the GP visit group and OR: $0.77,95 \% \mathrm{Cl}: 0.48-1.23$ for the specialist visit group). A similar proportion of Chinese and Whites reported that they always followed a physician's advice $(59.4 \%$ vs. $59.6 \%$ for the GP visit group and $67.2 \%$ vs. $62.8 \%$ for the specialist visit group). Non-English speaking Chinese and recent arrivals in Canada were less likely to be satisfied with GPs than Chinese born in Canada [risk adjusted OR: $0.5,95 \% \mathrm{Cl}: 0.3-0.9,0.2$ and $0.1-0.7$, respectively].

Conclusion: Chinese Canadians reported lower satisfaction with physicians and perceived physicians slightly more negatively than White Canadians. Particularly, Chinese with limited English and short length of stay in Canada were less satisfied than Canadian born Chinese.

\section{Background}

Patient satisfaction has become an important indicator of quality of primary care and healthcare system performance [1-3]. Low patient satisfaction is associated with lower trust in caregivers and greater chance of physician change - resulting in less continuity of care [4]. Not surprisingly, low patient satisfaction is also correlated to greater numbers of patient complaints and malpractice 
lawsuits $[5,6]$. Hence, the subject of patient satisfaction and how it benefits both patients and physicians has been widely studied.

It has been observed that various patient-physician interaction styles have had different effects on patient satisfaction $[7,8]$. Moreover, complaints in hospital settings are twice as likely to be related to communication problems as opposed to problems with medical skill [9]. Patientphysician belief congruence and high patient involvement in care have also been associated with higher trust and satisfaction [10-12]. These factors are all modifiable by physicians or patients, whereby, physicians should adapt to individual patient needs and patients should choose physicians that can adequately fill these needs.

Ethnic disparities in patient satisfaction have been examined in the United States, Australia, and the United Kingdom [13-18]. These studies have shown that Blacks, Hispanics, and Asians tend to rate their healthcare experiences less positively than their White counterparts. Among Asians specifically, lower satisfaction and trust have been consistently found [16,19-21]. Factors underlying these differences include education, socioeconomic status, physical and emotional health, health insurance coverage, healthcare costs, conflicting cultural views on healthcare, and communication difficulties.

Little is known about ethnic Canadians' satisfaction and compliance with physicians and previous study findings generated from other countries cannot be automatically generalized to the Canadian population for two major reasons. Firstly, the ethnic population in Canada differs noticeably from that in the United States and United Kingdom in terms of immigration history and ethnic composition. A majority of Canadian immigrants were selected based on their health status, education and technical skills in contrast to descendents of immigrants through labor forces in both the United States and the United Kingdom and slavery in the United States. Secondly, in the United States, insurance status and socioeconomic differences explain a significant part of the disparities in access to and use of healthcare services by ethnic minorities [22-24]. In Canada, where a universal healthcare system allows equal access to healthcare services, studies have shown that utilization of general practitioners (GPs) and specialists is similar in ethnic minorities and Whites [25]. For these reasons, there is a need for investigation into the healthcare experiences of Canadian ethnic minorities. In particular, the differences in perceptions of physicians by ethnic minorities and Whites and the reasons behind these differences need to be examined.

We conducted a telephone survey among Chinese and Whites in a large Canadian city to determine their reported satisfaction, perceptions of their GPs and specialists, and factors associated with these measurements among Chinese. Chinese Canadians were chosen because they represent the largest ethnic population (i.e. nonWhite and non-Aboriginal), accounting for over $25 \%$ of the ethnic population [26].

\section{Methods Study population}

This cross-sectional survey consisted of Chinese and White adults, living in the city of Calgary, Alberta, Canada from February to June 2005. The city is culturally diverse and individuals of Chinese descent make up the largest ethnic group among the ethnic population comprising $5.5 \%$ of the city's 1 million population [27]. We screened the surnames listed in the Calgary telephone directory in 2004 using the validated Chinese surname list to form the Chinese sampling frame from which a random sample was taken [28]. After exclusion of screened Chinese names from the telephone directory, we randomly selected phone numbers from the remaining numbers for the White sample.

The randomly selected telephone numbers were called and only one respondent was interviewed in each household. If there was more than one eligible respondent in the household, the one with the latest birth date was selected for the interview. We surveyed respondents meeting the following criteria: 1) self-identification as either Chinese or White, 2) 18 years of age or older, 3) a resident of Canada for a minimum of one year, and 4) contact with a physician in Canada. We excluded people who could not speak English, Cantonese or Mandarin. For the White sample, ethnicity of respondents was determined through the question: "People living in Canada come from many different cultural and racial backgrounds. How would you describe your ethnic origin?" The choices of White, Chinese, and other were provided. For the Chinese sample, we asked persons who answered the telephone: "Is there anyone at your household whose ethnic background is Chinese?" We interviewed individuals who answered 'Yes" and met the inclusion criteria.

\section{Questionnaire development and translation}

The questionnaire was first developed in English, including sociodemographic variables (gender, age, birthplace, length of stay in Canada, education level, language mainly spoken at home, marital status, and household income), presence of 15 chronic medical conditions (i.e. allergies, arthritis, back pain, cancer, depression, diabetes, headaches, heart disease, high blood pressure, kidney disease, liver disease, lung disease, neurological disorder including stroke, sleeping problems, and stomach diseases), past contact with physicians and perceptions of physicians. 
For those who had visited a GP or specialist in Canada, we asked: "1) How satisfied were you with the care you received from the doctor? 2) Did you feel that the doctor had adequate experience to treat your condition? 3) Did you feel comfortable asking the doctor questions? 4) Did you feel the doctor spent enough time with you? 5) Did you understand what the doctor said to you? 6) Did you feel the doctor listened carefully to you? 7) Do you trust the doctor so much that you always try to follow his/her advice?" The five-point Likert scale was used to measure level of satisfaction (very satisfied, satisfied, neither, dissatisfied and very dissatisfied). A four-point scale (yes definitely, yes to some extent, no and unsure) was employed to measure patients' compliance with physician advice, comfort level asking physician questions, opinion on physician's clinical experience, adequacy of time spent, clarity, and attentiveness.

The English questionnaire was forwardly and backwardly translated into Chinese. A different translator did each of these translations. An investigator fluent in both English and Chinese reviewed the back-translated English version. The questionnaire was tested among 11 Chinese and White adults using face-to-face interviews. The English and Chinese questionnaires were further revised based on comments and suggestion made by the test groups.

\section{Data collection}

Telephone interviewers were trained and practiced interviewing each other before the survey. Each of the randomly selected telephone numbers was called at different times of the day (i.e. evenings during weekdays and day time during weekends) up to 10 times. The Chinese survey was conducted in the respondent's preferred language by trained Chinese interviewers who were bi- or trilingual, speaking English, and Cantonese and/or Mandarin. The survey was conducted in English in the White sample. The University of Calgary Conjoint Health Research Ethics Board approved the survey and study methods.

\section{Data analysis}

Characteristics of the study population were described by comparing proportions within the two groups. Chisquare was employed to test the statistical significance of differences in study variables between the Chinese and White groups. Dichotomous dependent variables were constructed by letting the response 'very satisfied or satisfied" or "Yes, definitely" equal one and zero otherwise. We regressed the binary dependent variables onto demographic and health condition variables using logistic regressions. The survey was designed to achieve several objectives. Hence, no power calculations were conducted to determine the sample size for this particular study. However, the sample size of 711 for each ethic population was sufficient to detect the difference between two pro- portions (e.g. $70 \%$ and 63\%) with statistical power of 0.80 at $P$ value $=0.05$.

\section{Results}

Satisfaction, compliance and perceptions of physicians Of the 1727 Chinese and 1948 Whites contacted by phone, 850 (49.2\%) Chinese and 805 (41.3\%) Whites responded the survey. After exclusion of respondents without contact with either GPs or specialists, 746 Chinese and 711 Whites were analyzed in the GP visit group and 485 Chinese and 637 Whites were analyzed in the specialist visit group.

Table 1 describes the characteristics of the White and Chinese respondents in the GP and specialist visit groups. Compared with Whites surveyed, greater proportions of Chinese were younger than 65 years old, male, had university or higher education, and were married. Also, the Chinese surveyed had lower incomes on average than the Whites surveyed. Small proportions of Chinese spoke English at home $(10.7 \%)$ or were born in Canada $(8.8 \%)$. Additionally, Chinese tended to have fewer chronic health problems than Whites.

Table 2 shows patients' reported satisfaction, compliance and perceptions of physicians in the two ethnic groups. Compared with Whites, a lower proportion of Chinese reported very satisfied or satisfied with GP (73.7\% vs. $92.8 \%$ ) and specialist care (75.5\% vs. $85.6 \%$ ) and the differences between these two groups remained after adjustment for demographic variables and chronic conditions (risk adjusted odds ratio (OR): 0.70, 95\% confidence interval (95\%CI): $0.42-1.18$ for GP visit group and OR: 0.77, 95\%CI: 0.48-1.23 for specialist visit group, see Table 3). A similar proportion of Chinese and Whites reported that they always followed physician's advice (59.4\% vs. $59.6 \%$ for the GP visit group and $67.2 \%$ vs. $62.8 \%$ for the specialist visit group). In both GP and specialist visit groups, significantly fewer Chinese than Whites reported that physicians had adequate experience (44.2\% vs. $82.4 \%$ for the GP visit group, risk adjusted OR: $0.40,95 \%$ CI: $0.27-0.60$ and $58.8 \%$ vs. $84.5 \%$ for the specialist visit group, risk adjusted OR: 0.49, 95\%CI: $0.31-$ $0.77)$. For the GP visit group, Chinese were less likely than Whites to report that physicians spent enough time with them (33.8\% vs. $73.7 \%)$, that they felt comfortable asking questions (73.6\% vs. $89.6 \%$ ), and that they thought the physician listened to them carefully (63.4\% vs. $82.3 \%)$. This difference remained after adjustment for demographic variables and chronic conditions and all the adjusted ORs were statistically significant at the 95\% confidence level. 
Table I: Characteristics of Chinese and White Survey Respondents who Visited General Practitioners or Specialists

\begin{tabular}{|c|c|c|c|c|c|c|}
\hline \multirow[b]{2}{*}{ Variables } & \multicolumn{2}{|c|}{ General Practitioner Visits } & \multicolumn{4}{|c|}{ Specialist Visits } \\
\hline & $\begin{array}{c}\text { Chinese } \\
N(\% \text { of } 746)\end{array}$ & $\begin{array}{c}\text { White } \\
N(\% \text { of } 7 \mid I)\end{array}$ & P-Value & $\begin{array}{c}\text { Chinese } \\
N(\% \text { of } 485)\end{array}$ & $\begin{array}{c}\text { White } \\
N \text { (\% of 637) }\end{array}$ & P-Value \\
\hline \multicolumn{7}{|l|}{ Age } \\
\hline $18-34$ & $188(25.2)$ & $179(25.2)$ & $<0.001$ & $100(20.6)$ & $145(22.8)$ & 0.036 \\
\hline $35-64$ & $497(66.6)$ & $428(60.2)$ & & $335(69.1)$ & $398(62.5)$ & \\
\hline$\geq 65$ & $61(8.2)$ & $104(14.6)$ & & $50(10.3)$ & $94(14.8)$ & \\
\hline \multicolumn{7}{|l|}{ Gender } \\
\hline Male & $355(47.6)$ & $25 \mathrm{I}(35.3)$ & $<0.001$ & $204(42.1)$ & $225(35.3)$ & 0.021 \\
\hline Female & $391(52.4)$ & $460(64.7)$ & & $281(57.9)$ & $412(64.7)$ & \\
\hline \multicolumn{7}{|l|}{ Education } \\
\hline Less than senior High & $91(12.2)$ & $46(6.5)$ & $<0.001$ & $68(14.0)$ & $39(6.1)$ & $<0.001$ \\
\hline Senior High & $127(17.0)$ & $187(26.3)$ & & $92(19.0)$ & $166(26.1)$ & \\
\hline Technical/Professional College & $147(19.7)$ & $232(32.6)$ & & $103(21.2)$ & $204(32.0)$ & \\
\hline University or Higher & $38 I(5 I . I)$ & $246(34.6)$ & & $222(45.8)$ & $228(35.8)$ & \\
\hline \multicolumn{7}{|l|}{ Marital Status } \\
\hline Married/common-law & $585(78.4)$ & $426(59.9)$ & $<0.001$ & $388(80.0)$ & $385(60.4)$ & $<0.001$ \\
\hline Never married & $118(15.8)$ & $170(23.9)$ & & $63(13.0)$ & $152(23.9)$ & \\
\hline Divorced or Separated & $43(5.8)$ & $115(16.2)$ & & $34(7.0)$ & $100(15.7)$ & \\
\hline \multicolumn{7}{|l|}{ Income } \\
\hline$\leq 30,000$ & $204(27.3)$ & $86(12.1)$ & $<0.001$ & $124(25.6)$ & $74(11.6)$ & $<0.001$ \\
\hline $30,00 \mathrm{I}-50,000$ & $165(22.1)$ & $123(17.3)$ & & $97(20.0)$ & $116(18.2)$ & \\
\hline $50,00 I-70,000$ & $112(15.0)$ & $101(14.2)$ & & $87(17.9)$ & $88(13.8)$ & \\
\hline$>70,000$ & I8I (24.3) & $282(39.7)$ & & $124(25.6)$ & $260(40.8)$ & \\
\hline Missing & $84(11.3)$ & $119(16.7)$ & & $53(10.9)$ & $99(15.5)$ & \\
\hline \multicolumn{7}{|l|}{ Language Spoken at Home } \\
\hline English & $80(10.7)$ & $688(96.8)$ & $<0.001$ & $64(13.2)$ & $616(96.7)$ & $<0.001$ \\
\hline Chinese & $540(72.4)$ & $0(0.0)$ & & $335(69.1)$ & $0(0.0)$ & \\
\hline Both English and Chinese & $123(16.5)$ & $0(0.0)$ & & $84(17.3)$ & $0(0.0)$ & \\
\hline Other & $3(0.4)$ & $23(3.2)$ & & $2(0.4)$ & $21(3.3)$ & \\
\hline \multicolumn{7}{|l|}{ Birthplace } \\
\hline Canada & $66(8.8)$ & $607(85.4)$ & $<0.001$ & $44(9.1)$ & $545(85.6)$ & $<0.001$ \\
\hline Other Countries & $680(9 \mid .2)$ & $104(14.6)$ & & $44 \mid(90.9)$ & $92(14.4)$ & \\
\hline \multicolumn{7}{|l|}{ Length of Stay in Canada Among } \\
\hline \multicolumn{7}{|l|}{ Those Born Outside of Canada } \\
\hline I -4 years & $269(39.6)$ & $7(6.7)$ & & $143(32.4)$ & $4(4.3)$ & \\
\hline $5-9$ years & 135 (19.9) & $15(14.4)$ & & $86(19.5)$ & $13(14.1)$ & \\
\hline$\geq 10$ years & $276(40.6)$ & $82(78.8)$ & & $212(48.1)$ & $75(81.5)$ & \\
\hline \multicolumn{7}{|c|}{ Number of Conditions (out of I5) } \\
\hline Zero conditions & $337(45.2)$ & |4| (19.8) & $<0.001$ & $194(40.0)$ & $112(17.6)$ & $<0.001$ \\
\hline I condition & $21328.6)$ & $164(23.1)$ & & 140 (28.9) & $149(23.4)$ & \\
\hline 2 conditions & $117(15.7)$ & $142(20.0)$ & & $82(16.9)$ & $125(19.6)$ & \\
\hline 3 conditions & $43(5.8)$ & $106(14.9)$ & & $37(7.6)$ & $94(14.8)$ & \\
\hline$\geq 4$ conditions & $36(4.8)$ & $158(22.2)$ & & $32(6.6)$ & $157(24.6)$ & \\
\hline
\end{tabular}


Table 2: Disaggregated responses among Chinese and Whites who have visited General Practitioners or Specialists

\begin{tabular}{|c|c|c|c|c|c|c|}
\hline \multirow[b]{2}{*}{ Variables } & \multicolumn{2}{|c|}{ General Practitioner Visits } & \multicolumn{4}{|c|}{ Specialist Visits } \\
\hline & Chinese N (\% of 746) & White $N(\%$ of $7 \mathrm{II})$ & P-Value & Chinese $\mathrm{N}(\%$ of 485$)$ & White $N(\%$ of 637) & P-Value \\
\hline \multicolumn{7}{|c|}{ Satisfied with physician care } \\
\hline Very Satisfied & $158(2 \mid .2)$ & $420(59.1)$ & 0.0001 & $140(28.9)$ & $364(57.1)$ & 0.0001 \\
\hline Satisfied & $392(52.5)$ & $240(33.8)$ & & $226(46.6)$ & $|8|(28.4)$ & \\
\hline Neither & $153(20.5)$ & $30(4.2)$ & & $89(18.4)$ & $33(5.2)$ & \\
\hline Dissatisfied & $33(4.4)$ & $17(2.4)$ & & $20(4.1)$ & $25(3.9)$ & \\
\hline Very Dissatisfied & $5(0.7)$ & $2(0.3)$ & & $7(1.4)$ & $23(3.6)$ & \\
\hline Unsure & $5(0.7)$ & $2(0.3)$ & & $3(0.6)$ & II (I.7) & \\
\hline \multicolumn{7}{|c|}{$\begin{array}{l}\text { Definitely trust physician } \\
\text { enough to always follow } \\
\text { physician advice }\end{array}$} \\
\hline Yes Definitely & $443(59.4)$ & $424(59.6)$ & 0.606 & $326(67.2)$ & $400(62.8)$ & 0.003 \\
\hline Yes, to some extent & $267(35.8)$ & $242(34)$ & & $|3|(27)$ & $158(24.8)$ & \\
\hline No & $29(3.9)$ & $37(5.2)$ & & $21(4.3)$ & $62(9.7)$ & \\
\hline Unsure & $7(0.9)$ & $8(1.1)$ & & 7 (I.4) & $17(2.7)$ & \\
\hline \multicolumn{7}{|c|}{$\begin{array}{l}\text { Definitely felt physician had } \\
\text { adequate experience }\end{array}$} \\
\hline Yes Definitely & $330(44.2)$ & $586(82.4)$ & 0.0001 & $285(58.8)$ & $538(84.5)$ & 0.0001 \\
\hline Yes, to some extent & $361(48.4)$ & $103(14.5)$ & & $153(31.5)$ & $67(10.5)$ & \\
\hline No & $4 \mid(5.5)$ & $12(1.7)$ & & $28(5.8)$ & $19(3)$ & \\
\hline Unsure & $14(1.9)$ & $10(1.4)$ & & $19(3.9)$ & $13(2)$ & \\
\hline \multicolumn{7}{|c|}{$\begin{array}{l}\text { Definitely felt enough time was } \\
\text { spent with physician }\end{array}$} \\
\hline Yes Definitely & $252(33.8)$ & $524(73.7)$ & 0.0001 & $212(43.7)$ & $404(63.4)$ & 0.0001 \\
\hline Yes, to some extent & $335(44.9)$ & $132(18.6)$ & & $187(38.6)$ & $155(24.3)$ & \\
\hline No & $149(20)$ & $52(7.3)$ & & $81(16.7)$ & $68(10.7)$ & \\
\hline Unsure & $10(1.3)$ & $3(0.4)$ & & $5(1)$ & $10(1.6)$ & \\
\hline \multicolumn{7}{|c|}{$\begin{array}{l}\text { Definitely felt comfortable } \\
\text { asking physician questons }\end{array}$} \\
\hline Yes Definitely & $549(73.6)$ & $637(89.6)$ & 0.0001 & $343(70.7)$ & $494(77.6)$ & 0.001 \\
\hline Yes, to some extent & $173(23.2)$ & $61(8.6)$ & & $108(22.3)$ & $85(13.3)$ & \\
\hline No & $19(2.5)$ & $13(1.8)$ & & $26(5.4)$ & $49(7.7)$ & \\
\hline Unsure & $4(0.7)$ & $0(0)$ & & $8(1.6)$ & $9(1.4)$ & \\
\hline \multicolumn{7}{|c|}{$\begin{array}{l}\text { Definitely understood physician } \\
\text { explanation and advice }\end{array}$} \\
\hline Yes Definitely & $567(76)$ & $667(93.8)$ & 0.0001 & $278(57.3)$ & $516(8 I)$ & 0.0001 \\
\hline Yes, to some extent & $156(20.9)$ & $4 \mathrm{I}(5.8)$ & & $157(32.4)$ & $99(15.5)$ & \\
\hline No & $18(2.4)$ & $2(0.3)$ & & $49(10.1)$ & $16(2.5)$ & \\
\hline Unsure & $5(0.7)$ & $1(0.1)$ & & I $(0.2)$ & $6(0.9)$ & \\
\hline \multicolumn{7}{|c|}{$\begin{array}{l}\text { Definitely felt physician listened } \\
\text { carefully }\end{array}$} \\
\hline Yes Definitely & $473(63.4)$ & $585(82.3)$ & 0.0001 & $289(59.6)$ & $456(7 \mid .6)$ & 0.0001 \\
\hline Yes, to some extent & $238(31.9)$ & $112(15.8)$ & & $167(34.4)$ & $121(19)$ & \\
\hline No & $31(4.2)$ & $14(2)$ & & $21(4.3)$ & $50(7.8)$ & \\
\hline Unsure & $4(0.5)$ & $0(0)$ & & $8(1.6)$ & $10(1.6)$ & \\
\hline
\end{tabular}




\section{Factors associated with satisfaction, compliance and} perceptions of physicians among Chinese respondents

We restricted our analyses to Chinese only in order to assess factors associated with their reported satisfaction and compliance (see Table 4). After adjustment for sociodemographics and chronic health conditions, language spoken at home and birthplace were statistically significantly associated with their reported satisfaction, compliance and perceptions of physicians.

Non-English speaking Chinese and recent arrivals in Canada were less likely to be satisfied with GPs than Chinese born in Canada (risk adjusted OR: 0.5, 95\%CI: 0.3-0.9, 0.2 and $0.1-0.7$, respectively). Recent immigrants also rated GPs significantly lower than Canadian-born Chinese in terms of perceived clinical experience (risk adjusted OR: $0.3,95 \% \mathrm{CI}: 0.2-0.7)$, clarity of physicians' communication (risk adjusted OR: 0.3, 95\% CI: 0.1-0.9), and adequate time spent (risk adjusted OR: 0.2, 95\% CI: $0.1-0.5)$.

Recent immigrants were less likely to report following a specialist's advice compared with Canadian-born Chinese (OR: 0.3, 95\% CI: 0.1-0.8). Immigrants were also more likely to believe their specialist lacked clinical experience compared with Canadian-born Chinese (OR: 0.2, 95\% CI: $0.1-0.6$ for recent immigrants and OR: $0.3,95 \%$ CI: $0.1-$ 0.9 for those residing in Canada for 10 years or longer).

\section{Discussion}

We surveyed Chinese and White Canadians to examine their reported satisfaction, compliance and perceptions of physicians. We found that Chinese Canadians' physician satisfaction and perceptions differed from White Canadians. These findings were consistent with lower satisfaction ratings for physicians found among ethnic populations compared with Whites in the United Status, United Kingdoms and Australia [13-21]. This reported difference might be attributed to the views from our sample of recently immigrated Chinese. Our sample of recent immigrants was mainly from China (i.e. mainland China and Hong Kong) where the health care system is different from Canada's. China, particularly China's mainland, does not have an established primary care (GP) system and patients mainly visit physicians at outpatient departments of hospitals without appointments. Patients or a third party pay for physician services. Therefore, physicians in China attempt to satisfy their patients by providing prescriptions and diagnostics based on patient requests $[29,30]$. Recent immigrants to Canada might maintain these same expectations in their interactions with Canadian physicians. However, in Canada, physicians are seen primarily by appointment and necessity determines the prescription of drugs and diagnostics. These cultural factors may also have played a role in our finding that recent Chinese immigrants were more likely than non-immigrants to report that physicians lacked

Table 3: Satisfaction, Compliance, and Perceptions of Physicians among Chinese and Whites who have Visited General Practitioners or Specialists

\begin{tabular}{|c|c|c|c|c|c|c|c|c|}
\hline \multirow[b]{2}{*}{ Variables } & \multicolumn{2}{|c|}{$\begin{array}{c}\text { General Practitioner } \\
\text { Visits }\end{array}$} & \multirow[b]{2}{*}{ P-Value* } & \multicolumn{3}{|c|}{ Specialist Visits } & \multirow[b]{2}{*}{ P-Value* } & \multirow[b]{2}{*}{$\begin{array}{c}\text { Adjusted OR } \\
(95 \% \mathrm{Cl})^{\#} \\
\text { Chinese vs. Whit }\end{array}$} \\
\hline & $\begin{array}{l}\text { Chinese N } \\
\text { (\% of 746) }\end{array}$ & $\begin{array}{l}\text { White } N \\
\text { (\% of } 711)\end{array}$ & & $\begin{array}{c}\text { Adjusted OR } \\
(95 \% \mathrm{Cl})^{\#} \\
\text { Chinese vs. White }\end{array}$ & $\begin{array}{l}\text { Chinese N } \\
\text { (\% of 485) }\end{array}$ & $\begin{array}{l}\text { White N } \\
\text { (\% of 637) }\end{array}$ & & \\
\hline Satisfied with physician care & $550(73.7)$ & $660(92.8)$ & $<0.001$ & $0.70(0.42-1.18)$ & $366(75.5)$ & $545(85.6)$ & $<0.001$ & $0.77(0.48-1.23)$ \\
\hline $\begin{array}{l}\text { Definitely trust physician } \\
\text { enough to always follow } \\
\text { physician advice }\end{array}$ & $443(59.4)$ & $424(59.6)$ & 0.922 & $1.02(0.69-1.50)$ & $326(67.2)$ & $400(62.8)$ & 0.125 & $1.26(0.82-1.94)$ \\
\hline $\begin{array}{l}\text { Definitely felt physician had } \\
\text { adequate experience }\end{array}$ & $330(44.2)$ & $586(82.4)$ & $<0.001$ & $0.40(0.27-0.60)$ & $285(58.8)$ & $538(84.5)$ & $<0.001$ & $0.49(0.31-0.77)$ \\
\hline $\begin{array}{l}\text { Definitely felt enough time } \\
\text { was spent with physician }\end{array}$ & $252(33.8)$ & $524(73.7)$ & $<0.001$ & $0.38(0.26-0.56)$ & $212(43.7)$ & $404(63.4)$ & $<0.001$ & $0.66(0.44-1.00)$ \\
\hline $\begin{array}{l}\text { Definitely felt comfortable } \\
\text { asking physician questions }\end{array}$ & $549(73.6)$ & $637(89.6)$ & $<0.001$ & $0.53(0.34-0.82)$ & $343(70.7)$ & $494(77.6)$ & 0.009 & $1.02(0.65-1.60)$ \\
\hline $\begin{array}{l}\text { Definitely understood } \\
\text { physician explanations and } \\
\text { advice }\end{array}$ & $567(76.0)$ & $667(93.8)$ & $<0.001$ & $0.67(0.38-1.19)$ & $278(57.3)$ & $516(81.0)$ & $<0.001$ & $0.74(0.45-1.20)$ \\
\hline $\begin{array}{l}\text { Definitely felt physician } \\
\text { Listened carefully }\end{array}$ & $473(63.4)$ & $585(82.3)$ & $<0.001$ & $0.53(0.35-0.82)$ & $289(59.6)$ & $456(7 \mid .6)$ & $<0.001$ & $0.80(0.52-1.22)$ \\
\hline
\end{tabular}

Note:

* P-value is crude without risk adjustment

\# OR: Odds Ratio

95\% Cl: 95\% Confidence Interval

Age, gender, education, marital status, income, language, birthplace, and number of chronic conditions were adjusted for calculation of adjusted odds ratio 
Table 4: Factors Associated with Satisfaction, Compliance, and Perceptions of Physicians among Chinese who Visited General Practitioners or Specialists

\begin{tabular}{|c|c|c|c|c|c|c|c|}
\hline Variables & $\begin{array}{c}\text { Satisfaction OR } \\
(95 \% \mathrm{Cl})^{*}\end{array}$ & $\begin{array}{c}\text { Compliance OR } \\
(95 \% \mathrm{Cl})^{*}\end{array}$ & $\begin{array}{c}\text { Experience OR } \\
(95 \% \mathrm{Cl})^{*}\end{array}$ & $\begin{array}{l}\text { Time OR } \\
(95 \% \mathrm{Cl})^{*}\end{array}$ & $\begin{array}{c}\text { Questions OR } \\
(95 \% \mathrm{Cl})^{*}\end{array}$ & $\begin{array}{c}\text { Clarity OR } \\
(95 \% \mathrm{Cl})^{*}\end{array}$ & $\begin{array}{l}\text { Attentiveness } \\
\text { OR }(95 \% \mathrm{Cl})^{*}\end{array}$ \\
\hline \multicolumn{8}{|c|}{ Chinese Patients who Visited General Practitioners $(n=746)$} \\
\hline \multicolumn{8}{|l|}{ Language } \\
\hline English & 1.0 & 1.0 & 1.0 & 1.0 & 1.0 & 1.0 & 1.0 \\
\hline $\begin{array}{l}\text { Chinese or } \\
\text { Other }\end{array}$ & $0.5(0.3-0.9)$ & $1.2(0.8-1.7)$ & $0.7(0.4-1.0)$ & $1.0(0.7-1.6)$ & $0.8(0.5-1.3)$ & $0.7(0.4-1.2)$ & $0.9(0.6-1.4)$ \\
\hline \multicolumn{8}{|l|}{$\begin{array}{l}\text { Length of Stay } \\
\text { in Canada }\end{array}$} \\
\hline Born in Canada & 1.0 & 1.0 & 1.0 & 1.0 & 1.0 & 1.0 & 1.0 \\
\hline $1-9$ years & $0.2(0.1-0.7)$ & I.I (0.5-2.1) & $0.3(0.2-0.7)$ & $0.2(0.1-0.5)$ & $0.4(0.2-1.0)$ & $0.3(0.1-0.9)$ & $0.5(0.3-1.1)$ \\
\hline $\begin{array}{l}10 \text { or more } \\
\text { years }\end{array}$ & $0.5(0.1-1.7)$ & I.4 (0.7-2.7) & $0.8(0.4-1.6)$ & $0.6(0.3-1.1)$ & $0.7(0.3-1.6)$ & $0.7(0.2-1.9)$ & $0.7(0.4-1.5)$ \\
\hline
\end{tabular}

Chinese Patients who Visited Specialists $(n=485)$

\begin{tabular}{|c|c|c|c|c|c|c|c|}
\hline \multicolumn{8}{|l|}{ Language } \\
\hline English & 1.0 & 1.0 & 1.0 & 1.0 & 1.0 & 1.0 & 1.0 \\
\hline $\begin{array}{l}\text { Chinese or } \\
\text { Other }\end{array}$ & $0.7(0.4-1.2)$ & $1.5(0.9-2.5)$ & $1.0(0.6-1.7)$ & $0.6(0.4-1.0)$ & $0.6(0.4-1.1)$ & $0.4(0.2-0.7)$ & $0.8(0.5-1.3)$ \\
\hline \multicolumn{8}{|l|}{$\begin{array}{l}\text { Length of Stay } \\
\text { in Canada }\end{array}$} \\
\hline Born in Canada & 1.0 & 1.0 & 1.0 & 1.0 & 1.0 & 1.0 & 1.0 \\
\hline $1-9$ years & $0.5(0.1-1.6)$ & $0.3(0.1-0.8)$ & $0.2(0.1-0.6)$ & $0.4(0.2-1.0)$ & $0.7(0.2-1.9)$ & $1.0(0.4-2.6)$ & $0.6(0.2-1.5)$ \\
\hline $\begin{array}{l}10 \text { or more } \\
\text { years }\end{array}$ & $0.5(0.2-1.8)$ & $0.5(0.2-1.3)$ & $0.3(0.1-0.9)$ & $0.5(0.2-1.2)$ & $0.7(0.3-2.0)$ & $1.4(0.5-3.7)$ & $0.5(0.2-1.3)$ \\
\hline
\end{tabular}

Note: *Odds ratios ( $95 \%$ Confidence Intervals) were calculated after adjustment for age, sex, education, marital status, income, medical conditions, language and birthplace

Questions asked in the Survey:

Experience: Did you feel that the doctor had adequate experience to treat your condition?

Questions: Did you feel comfortable asking the doctor questions?

Time: Did you feel the doctor spent enough time with you?

Clarity: Did you understand what the doctor said to you?

Attentiveness: Did you feel the doctor listened carefully to you?

Compliance: Did you trust the doctor so much that you always try to follow his/her advice?

Satisfaction: How satisfied were you with the care you received from the doctor?

clinical experiences and did not spend enough time with them.

Chinese Canadians that did not speak English reported less satisfaction than those who spoke the language. These findings suggest that clear communication between physicians and patients still plays a significant role in patient perceptions of physicians. Hence, this is an area that should be improved when providing healthcare services. Translation services or selecting physicians proficient in a patient's first language may have some value [31-34]. It is notable, however, that patients who did not speak English reported following physician advice to the same degree as those speaking English. Our findings suggest that language and communication are important factors for patient satisfaction but satisfaction is not necessarily cor- related with patient compliance in the Chinese population.

Our study showed that a higher proportion of Chinese Canadians reported neutral levels of satisfaction (neither satisfied nor dissatisfied) and perception (yes to some extent) than White Canadians. This result might be related to Chinese cultural tendencies towards midpoint responses in measures associated with feelings or traits [35]. However, it is difficult to objectively quantify the effect of this cultural subjectivity on our measures without a population-based 'gold standard'. Hence, it should be emphasized that our study measured self-perceived rather than actual satisfaction and perceptions of physicians. Our results represented the combined effect of cultural subjectivity and expectations of physicians. We dichot- 
omized our satisfaction and perception measurements to capture patients who were 'definitively' satisfied or had a 'definitive' perception towards physicians. Our findings demonstrated an existing gap between Chinese and White Canada when self-perceived 'satisfaction' was used as a measure of the healthcare system or physician performance.

A limitation of this study is recall bias because our findings relied on participant recollection of their recent physician experiences. Second, the survey was conducted only in Calgary and involved only one of the many Canadian ethnic minorities. It is uncertain if these findings are generalizable to other ethnic populations. Third, the survey questions were designed for this study only and their validity was not assessed. Fourth, our response rate was not optimal and we could not quantify the differential bias between respondents and non-respondents in satisfaction and compliance. If Chinese respondents, for example, were more likely to have positive perceptions about their physician relative to Chinese non-respondents, we would produce over-estimates of satisfactions. Lastly, we did not ask respondents' for their physicians' ethnicity or comfort with the language spoken with the physician. Therefore, the impact of ethnic concordance between the patient and physician on satisfaction could not be assessed.

\section{Conclusion}

Chinese reported less satisfaction with physicians and perceived physicians slightly more negatively than Whites. Chinese with limited English and short length of stay in Canada reported less satisfaction than Canadian born Chinese. Physicians should strive to better fill the needs of their patients by paying particular attention to clarity and ensuring patient understanding. Possible tools for achieving this goal include the use of educational aids, language translation services and communication-specific physician training, specifically for recent immigrants and those with limited English language capacity. Physicians should also be aware that new immigrants may have different healthcare expectations Physicians should be sensitive to these possible cultural differences.

\section{Competing interests}

The author(s) declare that they have no competing interests.

\section{Authors' contributions}

RL participated in the statistical analysis of the paper and drafted the manuscript. LS performed the statistical analysis and critically reviewed the paper. HQ conceived of the study, participated in its design and coordination and helped to draft the manuscript. All authors read and approved the final manuscript.

\section{Acknowledgements}

Data used in this analysis was collected through a project funded by the Health Research Fund of the Alberta Heritage Foundation for Medical Research (AHFMR), Alberta, Canada. Richard Liu was funded by a Summer Studentship from AHFMR. Dr. Hude Quan is supported by a Population Health Investigator Award from AHFMR and by a New Investigator Award from the Canadian Institutes of Health Research, Canada.

\section{References}

I. Cleary PD, McNeil BJ: Patient satisfaction as an indicator of quality care. Inquiry 1988, 25(I):25-36.

2. Kurpas $D$, Steciwko A: [Patient satisfaction as the main indicator of primary care quality]. Przegl Lek 2005, 62 (I2): I546-5।.

3. Vuori $\mathrm{H}$ : Patient satisfaction - an attribute or indicator of the quality of care? QRB Qual Rev Bull 1987, 13(3): 106-8.

4. Keating NL, Green DC, Kao AC, Gazmararian JA, Wu VY, Cleary PD: How are patients' specific ambulatory care experiences related to trust, satisfaction, and considering changing physicians? J Gen Intern Med 2002, I 7(I):29-39.

5. Hickson GB, Clayton EW, Entman SS, Miller CS, Githens PB, Whetten-Goldstein K, Sloan FA: Obstetricians' prior malpractice experience and patients' satisfaction with care. JAMA 1994, 272(20): $1583-7$

6. Stelfox HT, Gandhi TK, Orav EJ, Gustafson ML: The relation of patient satisfaction with complaints against physicians and malpractice lawsuits. Am J Med 2005, I I 8(1 0): I I 26-33.

7. Flocke SA, Miller WL, Crabtree BF: Relationships between physician practice style, patient satisfaction, and attributes of primary care. J Fam Pract 2002, 5 I (10):835-40.

8. Levinson W, Roter DL, Mullooly JP, Dull VT, Frankel RM: Physicianpatient communication. The relationship with malpractice claims among primary care physicians and surgeons. JAMA 1997, 277(7):553-9.

9. Jimenez-Corona ME, Ponce-de-Leon-Rosales $S$, Rangel-Frausto $S$, Mohar-Betancourt A: Epidemiology of medical complaints in Mexico: identifying a general profile. Int / Qual Health Care 2006, 18(3):220-3.

10. Fiscella K, Meldrum S, Franks P, Shields CG, Duberstein P, McDaniel SH, Epstein RM: Patient trust: is it related to patient-centered behavior of primary care physicians? Med Care 2004, 42(I I): 1049-55.

II. Krupat E, Bell RA, Kravitz RL, Thom D, Azari R: When physicians and patients think alike: patient-centered beliefs and their impact on satisfaction and trust. J Fam Pract 200I, 50( I 2): 1057-62.

12. Krupat E, Hsu J, Irish J, Schmittdiel JA, Selby J: Matching patients and practitioners based on beliefs about care: results of a randomized controlled trial. Am J Manag Care 2004, I (I I Pt I):8I4-22

13. Campbell JL, Ramsay J, Green J: Age, gender, socioeconomic, and ethnic differences in patients' assessments of primary health care. Qual Health Care 200I, I0(2):90-5.

14. Haviland MG, Morales LS, Dial TH, Pincus HA: Race/ethnicity, socioeconomic status, and satisfaction with health care. Am J Med Qual 2005, 20(4): 195-203.

15. Haviland MG, Morales LS, Reise SP, Hays RD: Do health care ratings differ by race or ethnicity? Jt Comm J Qual Saf 2003, 29(3): 134-45

16. Murray-Garcia JL, Selby JV, Schmittdiel J, Grumbach K, Quesenberry CP Jr: Racial and ethnic differences in a patient survey: patients' values, ratings, and reports regarding physician primary care performance in a large health maintenance organization. Med Care 2000, 38(3):300-10.

17. Saha S, Arbelaez J], Cooper LA: Patient-physician relationships and racial disparities in the quality of health care. Am J Public Health 2003, 93(10): 1713-9.

18. Wong MD, Asch SM, Andersen RM, Hays RD, Shapiro MF: Racial and ethnic differences in patients' preferences for initial care by specialists. Am / Med 2004, I / 6(9):6 | 3-20.

19. Ngo-Metzger Q, Legedza AT, Phillips RS: Asian Americans' reports of their health care experiences. Results of a national survey. J Gen Intern Med 2004, I 9(2): I I I-9. 
20. Saha S, Hickam DH: Explaining low ratings of patient satisfaction among Asian-Americans. Am J Med Qual 2003, I 8(6):256-64.

21. Taira DA, Safran DG, Seto TB, Rogers WH, Kosinski M, Ware JE, Lieberman N, Tarlov AR: Asian-American patient ratings of physician primary care performance. J Gen Intern Med 1997, I 2(4):237-42.

22. Hargraves JL, Cunningham PJ, Hughes RG: Racial and ethnic differences in access to medical care in managed care plans. Health Serv Res 200I, 36(5):853-68.

23. Lasser KE, Himmelstein DU, Woolhandler S: Access to care, health status, and health disparities in the United States and Canada: results of a cross-national population-based survey. Am J Public Health 2006, 96(7): I300-7.

24. Shi L, Stevens GD: Disparities in access to care and satisfaction among U.S. children: the roles of race/ethnicity and poverty status. Public Health Rep 2005, I 20(4):43I-4I.

25. Quan H, Fong A, De Coster C, Wang J, Musto R, Noseworthy TW, Ghali WA: Variation in health services utilization among ethnic populations. CMAJ 2006, I 74(6):787-79I.

26. Statistics Canada, Census of Population: Visible minority population, by province and territory (200I Census). [http:// www40.statcan.ca/10I/cst0I/demo53e.htm]. Last updated January 25 , 2005, Accessed May 25, 2006.

27. Statistics Canada, Census of Population: Visible minority population, by census metropolitan areas (200I Census). [http:// www 40. statcan.ca/l0I/cst0l/demo53e.htm]. Last updated January 25 , 2005, Accessed May 25, 2006.

28. Quan H, Wang F, Schopflocher D, Norris C, Galbraith PD, Faris P, Graham MM, Knudtson ML, Ghali WA: Development and validation of a surname list to define Chinese ethnicity. Med Care 2006, 44(4):328-33.

29. Lam TP: Chinese fishermen's expectations on medications. Subst Use Misuse 2003, 38(I):85-96.

30. Tang KC, Easthope G: What constitutes treatment effectiveness? - the differential judgements of Chinese Australian patients and doctors. Complement Ther Med 2000, 8(4):24I-7.

3I. Green AR, Ngo-Metzger Q, Legedza AT, Massagli MP, Phillips RS, lezzoni LI: Interpreter services, language concordance, and health care quality. Experiences of Asian Americans with limited English proficiency. J Gen Intern Med 2005, 20(I I): 1050-6.

32. Lin EH: Intraethnic characteristics and the patient-physician interaction: "cultural blind spot syndrome". J Fam Pract 1983 16(I):91-8.

33. Ngo-Metzger Q, Massagli MP, Clarridge BR, Manocchia M, Davis RB, lezzoni LI, Phillips RS: Linguistic and cultural barriers to care. Gen Intern Med 2003, I 8(I):44-52.

34. Seid M, Stevens GD, Varni JW: Parents' perceptions of pediatric primary care quality: effects of race/ethnicity, language, and access. Health Serv Res 2003, 38(4): 1009-3I.

35. Lee JW, Jones PS, Mineyama Y, Xhang S: Cultural Differences in Responses to a Likert Scale. Research in Nursing \& Health 2002, 25:295-306.

\section{Pre-publication history}

The pre-publication history for this paper can be accessed here:

http://www.biomedcentral.com/1471-2296/8/11/prepub
Publish with Biomed Central and every scientist can read your work free of charge

"BioMed Central will be the most significant development for disseminating the results of biomedical research in our lifetime. "

Sir Paul Nurse, Cancer Research UK

Your research papers will be:

- available free of charge to the entire biomedical community

- peer reviewed and published immediately upon acceptance

- cited in PubMed and archived on PubMed Central

- yours - you keep the copyright
BioMedcentral 